\title{
Intestinal enzyme activities, Carcass biochemical composition and growth performance evaluation of Cirrhinus mrigala fed on heat processed soybean (Glycine max) supplemented diets
}

\author{
Anita Bhatnagar*, Neelam Rajharia and Oshin Dhillon \\ Department of Zoology, Kurukshetra University, Kurukshetra-136119 (Haryana), INDIA \\ ${ }^{*}$ Corresponding author's E-mail: anitabhatnagar@gmail.com
}

\section{ARTICLE HISTORY}

Received: 29 September 2017

Revised received: 06 November 2017

Accepted: 14 November 2017

\section{Keywords}

Cirrhinus mrigala

Excretion

Fish meal

Intestinal enzyme activities

Processed soybean

Supplemented diets

\begin{abstract}
The increasing cost and unpredictable availability of fishmeal and anti-nutritional factors of plant proteins necessitates the search on cheap and abundantly available protein source with capabilities of growth promotion. The feeding trial was conducted to evaluate the effect of hydrothermically processed soybean on growth performance, intestinal enzymatic activity and carcass composition for which three diets were formulated $T_{1}, T_{2}, T_{3}$ containing fish meal, raw soybean, and processed soybean, respectively. Cirrhinus mrigala fingerlings were stocked in glass aquaria $(60 \times 30 \times 30 \mathrm{~cm}) /$ plastic tubs (50L) for each diet in triplicates. Fingerlings were fed twice daily @ 4\% of wet body weight for 90 days. Length-weight measurements were done fortnightly to adjust the feed quantity. Significantly $(\mathrm{P}<0.05)$ high growth performance and low FCR were observed in the fingerlings fed with diet containing processed soybean. Crude protein (\%), crude fat (\%) and gross energy $\left(\mathrm{kJ} \mathrm{g}^{-1}\right)$ were found to be significantly $(\mathrm{P}<0.05)$ high in the carcass of fish fed with $\mathrm{T}_{3}$. Intestinal enzymatic activities were also significantly higher in the group $T_{3}$ than to those fed on fish meal and raw soybean. The excretion of ammonia and reactive phosphate was also low with the inclusion of processed soybean, indicating the good quality of water. Therefore, the use of hydrothermically processed soybean in the diets can help in substituting fish meal protein without compromising growth and digestibility parameters and the use of processed soybean in the diets can also eliminate or reduce the pollution problems associated with intensive aquaculture system.
\end{abstract}

C2017 Agriculture and Environmental Science Academy

Citation of this article: Bhatnagar, A., Rajharia, N. and Dhillon, O. (2017). Intestinal enzyme activities, Carcass biochemical composition and growth performance evaluation of Cirrhinus mrigala fed on heat processed soybean (Glycine max) supplemented diets. Archives of Agriculture and Environmental Science, 2(4): 264-269, DOI: 10.26832/24566632.2017.020403

\section{INTRODUCTION}

Successful and sustainable aquaculture is the need of time and it depends upon the provision of nutritionally adequate, environment friendly and economic viable artificial feeds. Fish meal has traditionally been used as a major protein source because of its high protein content and palatability. However, the increasing cost and unpredictable availability of fishmeal necessitates the search on its replacement with cheap and abundantly available plant protein feed stuffs. Soybean among plant protein has received maximum appreciation as alternative protein sources for fishmeal in aquafeed because of its consistent nutritional composition, comparatively balanced amino acid profile, availability, and reasonable price (Dabrowski and Kozak, 1979; Viola et al., 1983; Shiau et al., 1987 and Davies et al., 1989). Due to wide availability and consistent quality, soybean (Glycine max) derived products are being extensively used in fish feeds in recent years to partially replace the fish meal component (Azarm and Lee, 2012; Yong et al., 2013; Priyadarshini et al., 2015) which results in reduced feed cost. However, it contains endogenous anti-nutritional factors (ANFs) which accentuate digestive losses. These ANFs are inactivated by heat treatment, which allows dietary level at which such protein sources can be utilized by fish (Huisman and van der Poel, 1991; Tacon, 1993; Garg et al., 2002; Singh et al., 2003). Since soybean is considered to be deficient in lysine (Kaushik and Dabrowski, 1983), making it less available to fish, the diets needs a mineral premix (Kalla et al., 2001). Allan and Rowland (1994) and Singh et al. (2003) have also reported high apparent digestibility coefficients for a number of plant products in omnivorous silver perch and C. mrigala, respectively. As fishes are ammonotelic in nature, if fishmeal is provided to fish for increasing protein content in flesh, the nitrogen and phosphorus excretion in the holding water increases that pollute the water quality standards and that may lead to adverse effect on growth of fish.

The potential for increased use of soybean meal in aquaculture diets is substantial due to its nutritional value and cost effectiveness as compared to other feed stuffs. Increasing the availability of nutrients from soybean meal could possibly enhance the aquaculture production rate. Ammonia and phosphate production in the holding water was greater in diets with 
animal origin protein in comparison to plant origin proteins (Garg et al., 2002). Fewer studies have been so far conducted on excretion pattern of ammonia in relation to dietary protein in C. mrigala. Therefore, the present study was designed to quantify the effect on growth performance when processed soybean is included as protein source in the diet of economically important freshwater teleost C. mrigala.

\section{MATERIALS AND METHODS}

Experimental setup: Fingerlings with an average initial body weight of $0.24 \pm 0.02 \mathrm{~g}$ were procured from the "Jyotisar Fish Seed Farm" in Jyotisar, District Kurukshetra (Haryana) for the experiment and placed randomly in glass aquaria of $50 \mathrm{~L}$ capacity with dimensions of $60 \times 30 \times 30 \mathrm{~cm}$. Before starting the experiment, fingerlings were acclimated to the experimental system for 15 days. Each aquarium was filled with dechlorinated tap water, and then stocked with 10 fishes. The experiment was conducted under laboratory conditions $\left(25 \pm 1^{\circ} \mathrm{C}\right)$. Three dietary treatments were performed, in treatment 1 , fish were fed on artificial diet containing fishmeal and in treatment 2, fish were fed artificial diet containing raw soybean as major protein. In treatment 3, fish were fed on diet containing processed soybean. All these diets were isocaloric and isonitrogenous with approximately $40 \%$ protein (Kalla and Garg, 2003). Ingredient compositions of all diets are shown in Table 1. All groups of fish were fed daily at $4 \% \mathrm{BW}$ in two instalments at 08:00 and 16:30 hour for 90 days. Average weight of all fish in each tank was measured, and the amount of feed was adjusted accordingly every 15 days. Each group of fish was exposed to their respective diet for four hours; thereafter, the uneaten feed was siphoned out, stored, and dried separately for calculating feed consumption per day.

Preparation of formulated diet: Feed formulation was done basically by "square-method" using determined values (Table 2) of protein content of the ingredients. Each proportion of ingredients required was calculated precisely providing allowance for the mineral mixture. Soybean seeds were hydrothermically treated at $151 \mathrm{bs}$ pressure at $121^{\circ} \mathrm{C}$ for 15 minutes to remove anti-nutrient factors (ANFs). After oven drying at $60^{\circ} \mathrm{C}$ it was grounded into fine powder. All the ingredients groundnut oil cake, fish meal, rice bran, wheat flour, raw soybean and processed soybean were finely ground to pass through sieve of mesh size $0.5 \mathrm{~mm}$ prior the analysis of proximate composition. After proper mixing of all ingredients of experimental diets were mixed (quantity according to diet) and dough was made using distilled water and passed through a mechanical pellitizer to obtain pellets $(0.5 \mathrm{~mm}$ thick $)$ then dried in an oven. Then feeds so prepared were stored in airtight containers.

Analysis of parameters: Proximate analysis (Dry matter, ash, crude protein, crude fat, NFE and phosphorus) of experimental diets and fish carcass (initial and final) was done following (AOAC, 1995). Chromic oxide levels in the diets as well as in the fecal samples were estimated spectrophotometrically (Furukawa and Tuskahara, 1966). Growth and nutrient retention parameters were calculated following Steffens, 1989. Apparent protein digestibility (APD) of the diets was calculated according to of Cho et al. (1982). Live weight gain (g), percent weight gain, specific growth rate, feed consumption per day in percentage of body weight, feed conversion ratio (FCR), gross conversion efficiency (GCE), and protein efficiency ratio (GER) were calculated using standard method (Steffens, 1989). Gross energy content of the diet and fish carcasses was calculated using the average caloric conversion factor of $0.3954,0.1715$, and $0.2364 \mathrm{~kJ} \mathrm{~g}^{-1}$ for lipid, carbohydrate, and protein, respectively (Henken et al., 1986), whereas metabolizable energy in diets and feeds was calculated using caloric conversion factors: $0.335,0.138$, and $0.188 \mathrm{~kJ} \mathrm{~g}^{-1}$ for lipid, carbohydrate, and protein, respectively (Brett and Groves, 1979). Water quality two-hour intervals over a period of $24 \mathrm{~h}$ for the estimation of excretory levels of total ammonia $\left(\mathrm{N}-\mathrm{NH}_{4}{ }^{+}\right)$and reactive orthophosphate following the American Public Health Association (APHA, 2012), and calculated following Sumagaysay-Chavoso (2003). At the termination of experiment, the fish from all the treatments were individually weighed to the nearest gram and measured to the nearest millimeter and processed for subsequent analyses. From each treatment, eight fish were randomly sampled and kept on ice to remove the intestines which were processed for the determination of enzyme activity of protease (Walter, 1984), amylase (Sawhney and Singh, 2000), and cellulose (Sadasivam and Manickam, 1996).

Statistical analysis: Analysis of variance (ANOVA) followed by Duncan's multiple range test (Duncan, 1955) for all the experiments was used to determine the significant variation between the different treatments. Statistical significance was settled at a probability value of $P<0.05$. All statistical analysis was performed using SPSS Version 11.5 for Windows.

\section{RESULTS AND DISCUSSION}

In this experiment, three dietary treatments $\left(T_{1}\right.$ to $\left.T_{3}\right)$ were performed and the fish were fed on approximately isonitrogenous diets $(40 \%$ protein) for 90 days. In the first treatment fish were fed on a diets containing fishmeal. In the second treatment fish were fed on a diet consisting of raw soybean and in third treatment fish were fed on a diet consisting of hydrothermically processed soybean as the main protein source.

Proximate composition of formulated diet: Three isonitrogenous diets having fishmeal, raw soybean and processed soybean as main protein source were formulated. Crude fibre $(6.14 \pm 0.10$ to $6.77 \pm 0.17 \%)$ and total ash $(6.60 \pm 0.39$ to $7.51 \pm 0.21 \%$ ) were significantly high in the diets containing fishmeal, whereas gross energy $\left(\mathrm{kJ} \mathrm{g}^{-1}\right)$ was high in diet containing processed soybean. No significant $(P>0.05)$ variations were observed in the value of feed phosphorus (Table 3 ).

Growth, survival and digestibility: The growth responses of the test fish fed on experimental diets, containing fishmeal, raw soybean and processed soybean are shown in Table 4. Fish satisfactorily accepted the experimental diet from the beginning of the experiment and maintained normal behaviour throughout the experimental period. Survival rate (\%) was high in all the dietary treatment and slight mortality occurred only during the initial days of experiment. The growth of fish in terms of weight gain $(\mathrm{g})$, growth per day in percentage body weight and specific growth rate (SGR) were significantly $(P<0.05)$ high in treatment $\mathrm{T}_{3}$ where fish were fed on diet containing processed soybean in comparison to dietary treatments $T_{1}$ and $T_{2}$. Significantly $(P<0.05)$ high values of digestibility parameters viz., apparent protein digestibility (APD), gross conversion efficiency (GCE), protein efficiency ratio (PER) and lower values of food conversion ratio (FCR) were observed in treatment $\mathrm{T}_{3}$ where $C$. mrigala fingerlings were fed on diets containing processed soybean. The fish were bulk weighed at an interval of 15 days to calculate the ration to be given to the group of fish of particular treatment. The weight gain data revealed that there were not many varia- 
tions initially up to 15 days in the live weight gain of group of fishes fed on varying dietary treatments. However, growth rate increased significantly $(P<0.05)$ in the fish fed on diets containing processed soybean after 30 days till 90 days.

Intestinal digestive enzyme activity: Intestinal digestive enzyme activities for protease and amylase were determined. It was found that specific activity of digestive enzymes was significantly $(P<0.05)$ high in diets containing processed soybean as compared to diets containing raw soybean and fishmeal (Figure 1).

Proximate carcass composition: The carcass composition with respect to proximate nutrients of test fish on the basis of feeding trial is shown in Table 5. Crude protein (\%), crude fat $(\%)$ and gross energy $\left(\mathrm{kJ} \mathrm{g} \mathrm{g}^{-1}\right)$ were found to be significantly $(P<0.05)$ high in the carcass of fish fed on diets containing processed soybean. However, ash (\%) and moisture (\%) were found to be significantly $(P<0.05)$ high in fish fed on diet containing fishmeal.

Effect of three experimental diets on water quality characteristics: No significant variations were observed parameters pertaining to water quality characteristics except of excretion of metabolites in holding water. In general, significantly $(P<0.05)$ low values in total ammonia excretion and reactive phosphate production $\left(\mathrm{mg} \mathrm{Kg}^{-1} \mathrm{BW} \mathrm{d}^{-1}\right)$ were recorded in fish fed on diet containing processed soybean as compared diet containing fishmeal, and raw soybean (Figure 2). Peak values in $\mathrm{N}_{-} \mathrm{NH}_{4}{ }^{+}$excretion occurred approximately $6 \mathrm{~h}$ after the feed was given to the fish and thereafter levels gradually declined. While $\mathrm{O}-\mathrm{PO}_{4}$ production showed an initial high level at $2 \mathrm{~h}$ post feeding thereafter the levels declined.

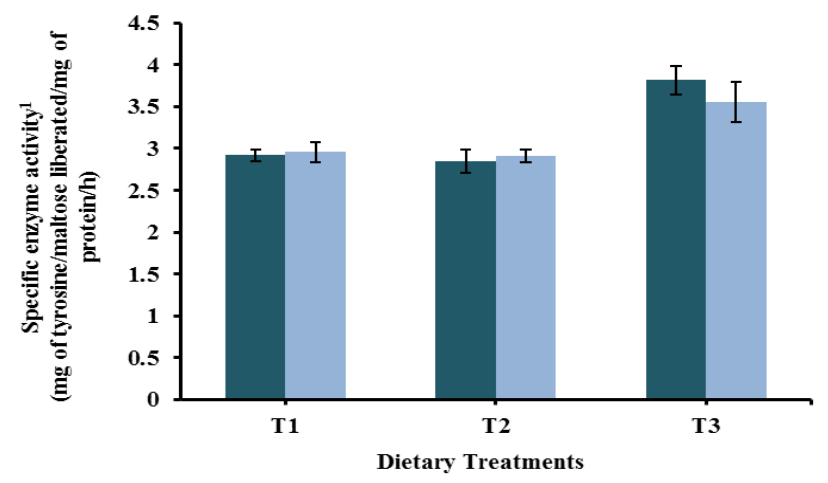

- Specific protease activity $\quad$ Specific amylase activity

Figure 1. Intestinal enzymatic activities of C. mrigala fed on different dietary treatments.

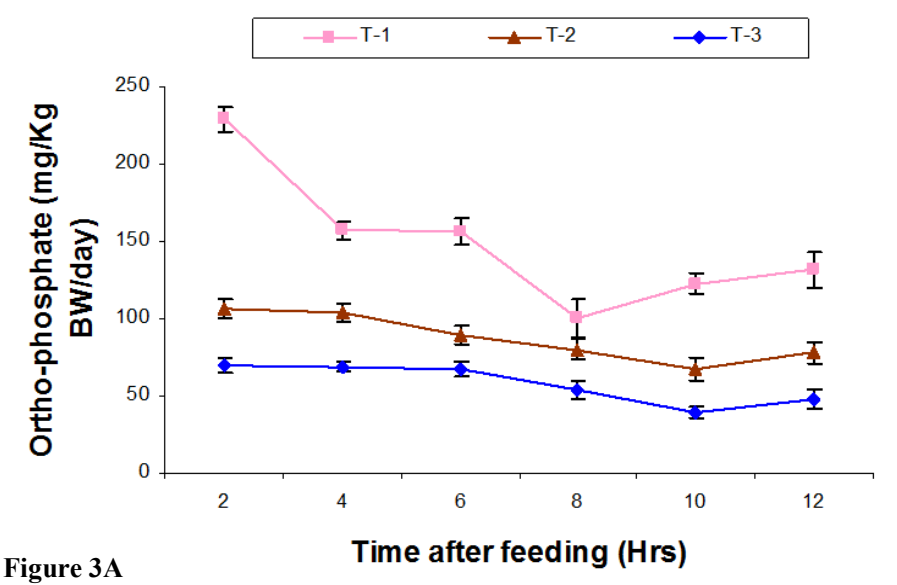

However, in some cases slight increase was observed at $12 \mathrm{~h}$ post feeding (Figures $3 \mathrm{~A}$ and $3 \mathrm{~B}$ ).

In the present studies, significantly $(P<0.05)$ higher growth and digestibility was observed in $C$. mrigala fed on diets containing hydrothermically treated soybean $\left(\mathrm{T}_{3}\right)$, indicates that hydrothermic treatment has helped in the elimination of antinutrient factors (ANF's) present in the soybean (Garg et al., 2002). Jackson et al. (1982); Shiau et al. (1987) have also reported poor growth in tilapia on replacing fish meal by raw soybean which was attributed to the presence of antinutrient factors present in the untreated soybean. Garg et al. (2002) have also observed poor growth performance in C. mrigala fingerlings fed on raw soybean protein in comparison with fingerlings fed on hydrothermically treated soybean which are in strong support of results of present studies.

Soybean products which are toasted in a proper way contain generally very low levels of lectins. Huisman and van der Poel (1991) concluded that trypsin inhibitors can be eliminated by atmospheric steaming $\left(102^{\circ} \mathrm{C}\right)$ and high temperature steaming for a short time may also provide an extra beneficial effect of nitrogen and amino acid digestibility. Sadiku and Jauncey (1998) have also observed that fish fed on diet containing autoclaved soybean did better than those fed on raw soybean flour. Webster et al. (1995) also obtained complete replacement of fish meal with soybean in the diet of blue catfish supplemented with methionine. In the present studies, soybean was hydrothermically processed at $121^{\circ} \mathrm{C}(15 \mathrm{lbs}$ for 15 minutes) before incorporation in the diet, perhaps this accounts for no degradation of essential amino acid, thus high growth and nutrient retention.

SGR, FCR, PER values obtained in the present studies on $C$.

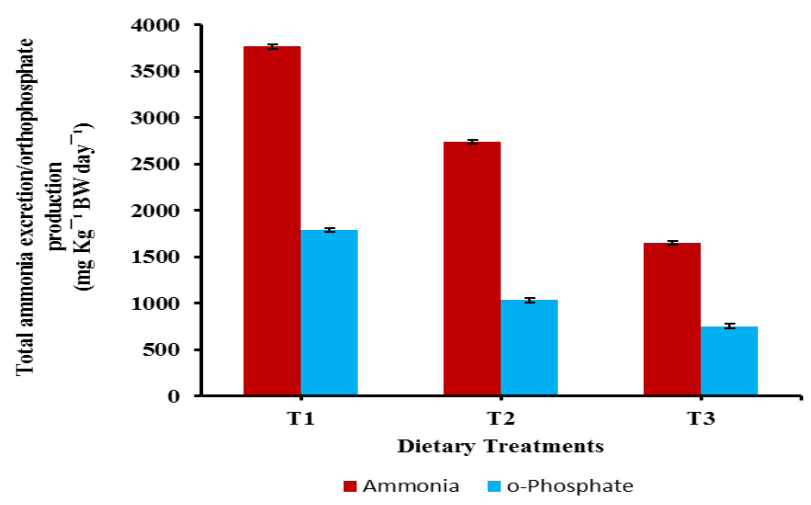

Figure 2. Post prandial excretory patterns of total ammonia and total orthophosphate ( $\mathrm{mg} \mathrm{Kg}^{-1}$ Body weight per day of fish) in holding water for fish C. mrigala in different dietary treatments.

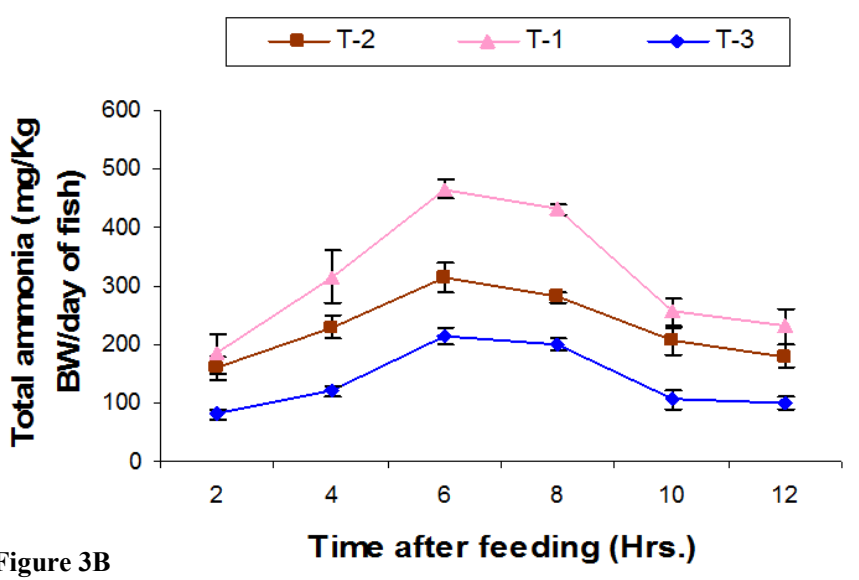

Figure 3. A,B: Excretory patterns of orthophosphate (2A) and total ammonia (2B), (mg/Kg Body weight of fish) in holding water for fish C. mrigala (Ham.) fingerlings fed on diets containing $\left(T_{1}\right)$, raw soybean $\left(T_{2}\right)$ and processed soybean $\left(T_{3}\right)$. 
mrigala are similar to those reported on Labeo rohita (Saha and Ray, 1998; Hossain et al., 1997), while GCE values were similar to those reported in European seabass (Ballestrazzi and Lanari, 1996). Inclusion of hydrothermically processed soybean in the present studies has resulted in low FCR and high APD. This may be attributed to its hydrothermal treatment of soybean for the inactivation of ANF's especially the trypsin inhibitor (Garg et al., 2002) increasing digestibility. The ANFs lowers the activity of digestive enzymes, reducing in digestibility. The present findings clearly indicate the significant high enzymatic activity in case of fish group fed on processed soybean devoid of ANFs. These findings thus strengthen the view that the enzyme systems in cyprinids, which have a long gut is better equipped to digest and absorb nutrients from plant feedstuffs (Jafri and Anwar, 1995), hence, better APD. The present investigation also depicts high values of protease and amylase in group of fishes fed with processed soybean based diets. With the incorporation of processed soybean in the diets, crude protein, fat accumulation and the energy values significantly $(\mathrm{P}<0.05)$ increased, while of ash decreased. These results appear to be in agreement to those of Ray and Das (1992) on Labeo rohita, Deepak and Garg (2003) in Heteropneustes fossilis. Thus, dietary heat processed soybean has been successfully applied for and aquatic animals (Azarm and Lee, 2012; Zhang et al., 2014).

Plant products contain fewer amounts of phosphate and nitrogen than animal protein therefore; the chances of eutrophication of pond could be minimized. Peak values in total ammonia excretion occurred $6-8 \mathrm{~h}$ after the feed distribution, whereas, the concentration of $\mathrm{O}-\mathrm{PO}_{4}$ in the aquaria were high 2-4 $\mathrm{h}$ post-feeding, returning to the basal levels thereafter and increasing again after $12 \mathrm{~h}$ for all the dietary treatments. Even though the excretory levels of total $\mathrm{N}-\mathrm{NH}_{4}{ }^{+}$and $\mathrm{O}-\mathrm{PO}_{4}$ production were reduced with the inclusion of processed soybean, however, diurnal patterns do not seem to be affected by the inclusion levels of soybean. These results are in agreement to those of Ballestrazzi et al. (1994); Singh (2001) and Kalla et al. (2001). This may be due to the reason of high protein present in fish meal, which on degradation results in high nitrogen in excretory products.

The excretory levels of total ammonia and reactive phosphate production were found to be negatively correlated with growth performance while a positive correlation was observed with FCR values. These findings are in conformation as suggested by Viola and Lahav (1993); Singh (2001); Garg et al. (2002); Deepak and Garg (2003), Priyanka and Garg (2002) and Raparia and Bhatnagar (2015). The growth performance increased while protein efficiency ratio (PER) linearly decreased when fish were fed on diets with increasing protein levels above the optimum requirement, indicating that the excess of dietary protein of fish meal would be delaminated, contributing to increased ammonia and reactive phosphate excretion. The results of these studies demonstrate that the use of hydrothermically processed soybean in the diets can help in substituting fish meal protein without compromising growth and digestibility parameters. The use of processed soybean thus may help the potential problems related with our dependence on fish meal supply.

Table 1. Proximate composition (\% dry basis) of diet ingredients.

\begin{tabular}{lccccc}
\hline Ingredients & Crude protein (\%) & Crude fat (\%) & Crude fiber (\%) & Ash (\%) & Moisture (\%) \\
\hline Processed soybean & $45.23 \pm 0.02$ & $17.79 \pm 0.18$ & $6.51 \pm 0.02$ & $3.83 \pm 0.02$ & $6.06 \pm 0.53$ \\
Raw soybean & $44.45 \pm 0.08$ & $18.30 \pm 0.05$ & $5.64 \pm 0.003$ & $3.58 \pm 0.02$ & $6.02 \pm 0.50$ \\
Fishmeal & $48.62 \pm 0.78$ & $8.05 \pm 0.02$ & $4.1 \pm 0.07$ & $28.16 \pm 0.2$ & $6.70 \pm 0.27$ \\
Rice bran & $12.18 \pm 0.23$ & $10.17 \pm 0.01$ & $16.64 \pm 0.04$ & $10.48 \pm 0.09$ & $8.68 \pm 0.37$ \\
Wheat flour & $11.28 \pm 0.23$ & $4.46 \pm 0.03$ & $10.83 \pm 0.03$ & $7.76 \pm 0.03$ & $8.48 \pm 0.29$ \\
Groundnut oil cake & $42.09 \pm 0.23$ & $5.68 \pm 0.04$ & $8.29 \pm 0.04$ & $5.97 \pm 0.03$ & $6.72 \pm 0.27$ \\
\hline
\end{tabular}

*Soybean was hydrothermically processed in an autoclave at $121^{\circ} \mathrm{C}(15 \mathrm{lbs}$ for 15 minutes $)$ to eliminate antinutrient factors $(\mathrm{Garg}$ et al., 2002).

Table 2. Ingredient contents $\left(\mathrm{g} \mathrm{Kg}^{-1}\right)$ of artificial diets.

\begin{tabular}{|c|c|c|c|}
\hline Ingredients & $\mathbf{T}_{1}$ & $\mathbf{T}_{2}$ & $\mathbf{T}_{3}$ \\
\hline Ground oil cake & 650.0 & 650.0 & 650.0 \\
\hline Rice Bran & 42.0 & 42.0 & 42.0 \\
\hline Fish meal & 266 & - & - \\
\hline Raw soybean & - & 266 & - \\
\hline Processed soybean ${ }^{*}$ & - & - & 266 \\
\hline Wheat flour & 32.0 & 32.0 & 32.0 \\
\hline Mineral mixture ${ }^{* *}$ & 10.0 & 10.0 & 10.0 \\
\hline $\mathrm{Cr}_{2} \mathrm{O}_{3}$ & 10.0 & 10.0 & 10.0 \\
\hline
\end{tabular}

*Soybean was hydrothermically processed in an autoclave at $121^{\circ} \mathrm{C}(15 \mathrm{lbs}$ for 15 minutes) to eliminate antinutrient factors (Garg et al., 2002$)$; $* *$ Each $\mathrm{kg}$ has nutritional value: copper $312 \mathrm{mg}$, cobalt $35 \mathrm{mg}$, magnesium $2.114 \mathrm{~g}$, iron $979 \mathrm{mg}$, zinc $2 \mathrm{mg}$, iodine $15 \mathrm{mg}$, DL-methionine 1.920 g, L-lysine monohydrochloride $4.4 \mathrm{~g}$, calcium $30 \%$, phosphorous $8.25 \%$.

Table 3. Proximate composition (\% dry weight) of experimental diets.

\begin{tabular}{lccc}
\hline Proximate Analysis & $\mathbf{T}_{\mathbf{1}}$ (Fish meal) & $\mathbf{T}_{\mathbf{2}}$ (Raw soybean) & $\mathbf{T}_{\mathbf{3}}$ (Processed soybean) \\
\hline Crude protein (\%) & $39.98 \pm 1.16^{\mathrm{A}}$ & $41.31 \pm 1.43^{\mathrm{A}}$ & $39.85 \pm 1.36^{\mathrm{A}}$ \\
Crude fat (\%) & $9.65 \pm 0.38^{\mathrm{A}}$ & $8.56 \pm 0.47^{\mathrm{A}}$ & $9.10 \pm 0.26^{\mathrm{A}}$ \\
Crude fiber (\%) & $6.77 \pm 0.17^{\mathrm{A}}$ & $6.14 \pm 0.10^{\mathrm{B}}$ & $6.23 \pm 0.06^{\mathrm{B}}$ \\
Total ash (\%) & $7.51 \pm 0.21^{\mathrm{A}}$ & $7.45 \pm 0.26^{\mathrm{A}}$ & $6.60 \pm 0.39^{\mathrm{B}}$ \\
Moisture (\%) & $7.68 \pm 0.23^{\mathrm{A}}$ & $8.27 \pm 0.21^{\mathrm{A}}$ & $7.41 \pm 0.20^{\mathrm{A}}$ \\
Nitrogen free extract (\%) & $26.58 \pm 1.25^{\mathrm{A}}$ & $25.65 \pm 1.61^{\mathrm{A}}$ & $29.30 \pm 1.42^{\mathrm{A}}$ \\
Gross energy (kJ g $\left.{ }^{-1}\right)$ & $17.65 \pm 0.06^{\mathrm{B}}$ & $17.78 \pm 0.06^{\mathrm{B}}$ & $17.93 \pm 0.09^{\mathrm{A}}$ \\
\hline
\end{tabular}

All values are mean \pm SE of mean; Means with same letter in the same row are not significantly $(\mathrm{P}<0.05)$ different; Data were analysed by Duncan's Multiple Range test. 
Table 4. Growth performances of $C$. mrigala fed on diets containing fishmeal $\left(\mathrm{T}_{1}\right)$, raw soybean $\left(\mathrm{T}_{2}\right)$ and processed soybean $\left(\mathrm{T}_{3}\right)$.

\begin{tabular}{lccc}
\hline Growth parameters & $\mathbf{T}_{\mathbf{1}}$ (Fish meal) & $\mathbf{T}_{\mathbf{2}}$ (Raw soybean) & T $_{\mathbf{3}}$ (Processed soybean) \\
\hline Initial weight (g) & $0.31 \pm 0.02^{\mathrm{A}}$ & $0.31 \pm 0.02^{\mathrm{A}}$ & $0.31 \pm 0.02^{\mathrm{A}}$ \\
Final weight (g) & $0.90 \pm 0.03^{\mathrm{B}}$ & $0.82 \pm 0.03^{\mathrm{B}}$ & $1.13 \pm 0.01^{\mathrm{A}}$ \\
Live weight gain (g) & $0.58 \pm 0.06^{\mathrm{B}}$ & $0.51 \pm 0.02^{\mathrm{B}}$ & $0.82 \pm 0.03^{\mathrm{A}}$ \\
Survival rate (\%) & $90.48^{\mathrm{B}}$ & $81.91^{\mathrm{C}}$ & $100^{\mathrm{A}}$ \\
Growth (\%) gain in BW & $191.6 \pm 36.49^{\mathrm{B}}$ & $166.0 \pm 15.22^{\mathrm{B}}$ & $268.1 \pm 14.67^{\mathrm{A}}$ \\
Growth per day (\%) in BW & $1.06 \pm 0.10^{\mathrm{B}}$ & $1.00 \pm 0.05^{\mathrm{B}}$ & $1.26 \pm 0.06^{\mathrm{A}}$ \\
Specific growth rate (SGR) (\% BW d ${ }^{-1}$ ) & $1.16 \pm 0.13^{\mathrm{B}}$ & $1.08 \pm 0.06^{\mathrm{B}}$ & $1.43 \pm 0.10^{\mathrm{A}}$ \\
Feed conversion ratio (FCR) & $1.57 \pm 0.16^{\mathrm{A}}$ & $1.53 \pm 0.08^{\mathrm{A}}$ & $1.18 \pm 0.04^{\mathrm{B}}$ \\
Gross conversion efficiency (GCE) & $0.63 \pm 0.06^{\mathrm{B}}$ & $0.65 \pm 0.03^{\mathrm{B}}$ & $0.84 \pm 0.03^{\mathrm{A}}$ \\
Protein efficiency ratio (PER) & $0.01 \pm 0.001^{\mathrm{B}}$ & $0.01 \pm 0.00^{\mathrm{B}}$ & $0.02 \pm 0.002^{\mathrm{A}}$ \\
Apparent protein digestibility (APD \%) & $62.3 \pm 0.4^{\mathrm{B}}$ & $65.2 \pm 0.3^{\mathrm{B}}$ & $76.8 \pm 0.15^{\mathrm{A}}$ \\
\hline
\end{tabular}

All values are mean \pm SE of mean; Means with same letter in the row are not significantly $(\mathrm{P}<0.05)$ different. Data were analysed by Duncan's Multiple Range test.

Table 5. Proximate carcass composition of $C$. mrigala fed on diets containing fishmeal $\left(T_{1}\right)$, raw soybean $\left(T_{2}\right)$ and processed soybean $\left(T_{3}\right)$.

\begin{tabular}{lcccc}
\hline Proximate composition & Initial value & $\mathbf{T}_{\mathbf{1}}$ (Fish meal) & $\mathbf{T}_{\mathbf{2}}$ (Raw soybean) & $\mathbf{T}_{\mathbf{3}}$ (Processed soybean) \\
\hline Moisture (\%) & $71.27 \pm 0.05$ & $69.24 \pm 0.02^{\mathrm{A}}$ & $68.58 \pm 0.02^{\mathrm{B}}$ & $68.22 \pm 0.02^{\mathrm{B}}$ \\
Crude protein (\%) & $8.08 \pm 0.04$ & $8.84 \pm 0.02^{\mathrm{C}}$ & $10.36 \pm 0.29^{\mathrm{B}}$ & $12.33 \pm 0.17^{\mathrm{A}}$ \\
Crude fat (\%) & $2.83 \pm 0.05$ & $5.01 \pm 0.04^{\mathrm{C}}$ & $5.23 \pm 0.08^{\mathrm{B}}$ & $6.83 \pm 0.04^{\mathrm{A}}$ \\
Total ash (\%) & $3.52 \pm 0.01$ & $8.39 \pm 0.03^{\mathrm{A}}$ & $4.19 \pm 0.04^{\mathrm{B}}$ & $3.91 \pm 0.03^{\mathrm{C}}$ \\
Nitrogen free extract (\%) & $14.28 \pm 0.11$ & $8.50 \pm 0.05^{\mathrm{B}}$ & $11.55 \pm 0.11^{\mathrm{A}}$ & $8.7 \pm 0.19^{\mathrm{C}}$ \\
Gross energy (kJ g & & & $7.10 \pm 0.02^{\mathrm{A}}$ \\
\hline
\end{tabular}

All values are mean \pm SE of mean; Means with same letter in the row are not significantly $(\mathrm{P}<0.05)$ different. Data were analysed by Duncan's Multiple Range test.

\section{Conclusions}

The use of hydrothermically treated plant origin protein in the diets can substitute the use of fish meal protein and anti-nutritional factors of raw plant without compromising growth rate, nutrient retention and flesh quality as this improves digestibility by successfully eliminating antinutrient factors like trypsin inhibitors. The use of processed soybean in the diets can also eliminate or reduce the pollution problems associated with intensive aquaculture system.

Open Access: This is open access article distributed under the terms of the Creative Commons Attribution License, which permits unrestricted use, distribution, and reproduction in any medium, provided the original author(s) and the source are credited.

\section{REFERENCES}

Allan, G.L. and Rowland, S.J. (1994). The use of Australian oilseeds and grain legumes in aquaculture diets. In L.M. Chou, A.D. Munro, T.J. Lam, T.W. Chen, L.K.K. Cheong, J.K. Ding, K.K. Hooi, H.W. Khoo, V.P.E. Phang, K.F. Shim \& C.H. Tan (Eds.), The Third Asian Fisheries Forum, pp: 667-670.

AOAC, Association of Official Analytical Chemists (1995). Official methods of analysis. Association of Official Analytical Chemists International, Arlington, USA.

APHA, American Public Health Association (2012). Standard methods for the examination of water and waste water. APHA, AWWA, WPFC, $23^{\text {th }}$ ed. New York.

Azarm, H.M. and Lee, S.M. (2012). Effects of partial substitution of dietary fish meal by fermented soybean meal on growth performance, amino acid and biochemical parameters of juvenile black sea bream Acanthopagrus schlegeli. Aquaculture Research, 1-10.

Ballestrazzi, R. and Lanari, D. (1996). Growth body composition and nutrient retention efficiency of growing sea bass (Dicentrarchus labrax L.) fed fish oil or fatty acid Ca salts. Aquaculture, 139:
101-108.

Ballestrazzi, R., Lanari, D., Agaro, E.D. and Mion, A. (1994). The effect of dietary protein level and source on growth, body composition, total ammonia and reactive phosphate excretion of growing seabass (Dicentrarchus labrax). Aquaculture, 127: 197-206.

Brett, J.R. and Groves, T.D.D. (1979). Physiological energetics. In W.S. Hoar, D.J. Randall \& J.R. Brett (Eds.), Fish Physiology Vol. 8 (pp. 280-351), Academic Press Inc., New York, NY.

Cho, C.Y., Hines, J.D., Wood, K.R. and Yoshida, H.K. (1982). Quantitation of fish culture wastes by biological (nutritional) and chemical (limnological) methods; the development of high nutrient dense (HND) diets. In C. B. Cowey \& C. Y. Cho (Eds.), Nutritional Strategies and Aquaculture Waste (pp. 3750). Proceedings of the First International Symposium on Nutritional Strategies in Management of Aquaculture Waste, University of Guelph, Guelph, Ontario, Canada.

Dabrowski, K. and Kozak, B. (1979). The use of fish meal and soybean meal as a protein source in the diet of grass carp fry. Aquaculture, 18: 107-114.

Davies, S.J., Thomas, N. and Bateson, R.L. (1989). The nutritional value of a processed soya protein concentrate in diets for tilapia fry (Oreochromis mossambicus Peters). Bamidgeh, 41: 3-11.

Deepak, K. and Garg, S.K. (2003). Effect of replacement of fish meal with soybean protein on growth and digestibility in the catfish, Heteropneustes fossilis (Bloch.). NATCON, 15(1): 131137.

Duncan, D.B. (1955). Multiple range and multiple F- test. Biometrics, 11: 1-42.

Furukawa, A. and Tuskahara, H. (1966). On the acid digestion method for determination of chromic oxide as an indicator substance in the study of digestibility in fish. Bulletin of the Japanese Society of the Science of Fish, 32: 502-506.

Garg, S.K., Kalla, A. and Bhatnagar, A. (2002). Evaluation of raw and hydrothermically processed leguminous seeds as supplementary feed for the growth of two Indian major carp species. Aquaculture Research, 33: 151-163.

Henken, A.H., Lucas, H., Tijssen, P.A.T. and Machiels, M.A.M. 
(1986). A comparison between methods used to determine the energy content of feed, fish and faeces samples. Aquaculture, 58 (3-4): 195-201.

Hossain, M. A., Nahar, N. and Kamal, M. (1997). Nutrient digestibility coefficients of some plant and animal proteins for rohu Labeo rohita. Aquaculture, 151: 37-45.

Huisman, J. and van der Poel, A.F.B. (1991). Antinutrition factors (ANF) in cattle feedstuff for pigs and chicken (pp. 17). PHLO curcus cattle feed, Wageningen.

Jackson, A.J., Capper, B.S. and Matty, A.J. (1982). Evaluation of some plant proteins in complete diets for the tilapia Sarotherodon mossambicus. Aquaculture, 27: 97-109.

Jafri, A.K. and Anwar, M.F. (1995). Protein digestibility of some low-cost feedstuffs in fingerlings Indian major carps. Asian Fisheries Science, 8: 47-53.

Kalla, A. and Garg, S.K. (2003). Comparative evaluation of dietary protein source and level on growth performance and nutrient retention in Mugil cephalus (Linn) fry. Journal of Aquaculture, 11: 59-69.

Kalla, A., Kaushik, C.P., Garg, S.K. and Bhatnagar, A. (2001). Role of plant protein in sustainable aquaculture. In A.G. Ponniah, K. K. Lal \& V.S. Bsheer (Eds.), NBFGR-NATP publication No.3. Captive breeding for Aquaculture and Fish Germplasm Conservation, Paper No. 38, pp: 1-2.

Kaushik, S.J. and Dabrowski, K. (1983). Nitrogen and energy utilization in juvenile carp (Cyprinus carpio) fed casein, amino acids or a protein-free diet. Reproduction Nutrition Development, 23 (4): 741-754.

Priyadarshini, M., Manissery, J. K., Gangadhara, B., Rao, L. M. and Keshavanath, P. (2015). Growth performance, body composition and digestive enzyme activity of common carp (Cyprinus carpio) fry fed on soybean and horse gram supplemented diets. International Journal of Aquaculture, 5(17): 1-7.

Priyanka and Garg, S.K. (2002). Replacement of fish meal with canola (rapeseed) enhances growth performance in the catfish, Heteropneustes fossilis (Bloch.). Environment and Ecology, 20(3): 732736

Raparia, S. and Bhatnagar, A. (2015) Effect of dietary protein source and probiotic inclusion on pattern of excretion of ammonia and orthophosphate in holding water in Catla catla culture system. International Journal of Fisheries and Aquatic Studies, 4(1): 0107.

Ray, A.K. and Das, I. (1992). Utilization of diets containing composed aquatic weed (Salvinia cuculata) by the Indian major carp, rohu (Labeo rohita Ham.) fingerlings. Bioresource Technology, 40: 67-72.

Sadasivam, S. and Manickam, A. (1996). Biochemical methods (pp. 107-109), New Age International Publishers, New Delhi, India.
Sadiku, S.O.E. and Jauncey, K. (1998). Utilisation of enriched soybean flour by Clarias gariepinus. Journal of Aquaculture in the Tropics, 13(1): 1-10.

Saha, A.K. and Ray, A.K. (1998). Evaluation of chuni, a commercially available low-cost cattle fodder, in the diet for rohu, Labeo rohita (Hamilton), fingerlings. Aquaculture Research, 29: 761-768.

Sawhney, S.K. and Singh, R. (2000). Introductory Practical Biochemistry. Narosa Publishing House, New Delhi, India.

Shiau, S.Y., Chuang, J.L. and Sun, C.L. (1987). Inclusion of soybean in tilapia (Oreochormis niloticus $\times$ O. aureus) diets at two protein levels. Aquaculture, 65: 251-261.

Singh, K., Garg, S.K., Kalla, A. and Bhatnagar, A. (2003). Oilcakes as protein source in supplementary diets for the growth of Cirrhinus mrigala (Ham.) fingerlings: laboratory and field studies. Bioresource Technology, 86: 283-191.

Singh, K.S. (2001). Effect of supplementary feeds on survival and growth performance of Indian major carp fry and fingerlings. M.Sc. Thesis, CCS Haryana Agricultural University, Hissar, Haryana, India.

Steffens W. (1989). Principles of Fish Nutrition, New York. Chichester, Brisbane, Toronto, Horwood, $384 \mathrm{pp}$.

Sumagaysay-Chavoso, N.S. (2003). Nitrogen and phosphorus digestibility and excretion of different-sized groups of milkfish (Chanos chanos forsskal) fed formulated and natural food-based diets. Aquaculture Research, 34: 407-418.

Tacon, A.G.J. (1993). Feed ingredients for warm water fish. Fish meal and other processed feed stuffs, FAO, Rome, Italy.

Viola, S. and Lahav, E. (1993). The protein sparing effect of supplemental lysine in practical carp feeds. Colloques de l'INRA (France).

Viola, S., Mokady, S. and Arieli, S. (1983). Effects of soybean processing methods on the growth of carp (Cyprinus carpio). Aquaculture, 32: 27-28.

Walter, H.E. (1984). Probionases: Methods with haemoglobin, casein and azocoll as substrates. In H.U. Bergmeyer (Eds.), Methods of Enzymatic Analysis (pp. 270-277). Verlag Chemic, Weinheim.

Webster, C.D., Goodgame-Tiu, L.S and Tidwell, J.H. (1995). Total replacement of fish meal by soybean meal, with various percentages of supplemental L-methionine in diets of blue catfish, Ictalurus furcatus (Lesueur). Aquaculture Research, 26: 299-306.

Yong, A.S.K., Ooi, S.Y. and Shapawi, R. (2013). The utilization of soybean meal in formulated diet for marble goby, Oxyeleotris marmoratus. Journal of Agricultural Science, 5 (11): 139-149.

Zhang, Y.Q., Wu, Y.B., Jiang, D.L., Qin, J.G. and Wang, Y. (2014). Gamma-irradiated soybean meal replaced more fish meal in the diets of Japanese seabass (Lateolabrax japonicus). Animal Feed Science Technology, 197: 155-163. 